\title{
Two three-holed stone anchors from Kommos, Crete: their context, type and origin
}

\author{
Joseph W. Shaw* \\ Department of Fine Art, University of Toronto, Toronto, Ontario, Canada M5S 1A1
}

\section{Introduction}

This article discusses two three-holed stone anchors recently discovered at Kommos, a Minoan and Greek site on the south coast of Crete $^{[1]}$. The Minoan settlement was inhabited from Middle Minoan I through Late Minoan IIIB, c. $2000 \mathrm{BC}$ to $1250 \mathrm{BC}$, and is topographically divided into two areas, the town and the civic centre with two monumental ashlar buildings. The earlier, Building $\mathrm{T}$, with a palatial plan and a large central court, was built and also went out of use in LM IA, but many of its walls and spaces were later re-used. During LM IIIA2 Building $\mathrm{P}$ was built upon its eastern wing.

\section{Context}

The two anchors were found in a level that can be attributed to an intermediary period: after the palatial building went out of use and before Building $\mathrm{P}$ took its characteristic form of six long parallel galleries opening towards the sea. The anchors were in situ, used as bases, along with four other stones (S 2232, S 2235-S 2237), set at intervals of about $2.30 \mathrm{~m}$ and with their tops at about the same level $(+3.23 \mathrm{~m}-+3.29 \mathrm{~m}$ above present sea level). The bases were set into beddings cut through an LM I plaster floor on an east-west line along part of the longitudinal axis of Gallery 3 , and were probably used as temporary supports for P's roof during the process of construction.

\footnotetext{
*With contributions from Marie-Pierre Aubry, William A. Berggren and Andrew Miall.
} $1057-2414 / 95 / 040279+13 \$ 12.00 / 0$
The latest sherds found in the beddings and below the level of the tops of the anchors were of LM IIIA1 date, and included (in the case of anchor S 2234) Canaanite and Cypriot sherds. In addition, two fragments of Egyptian amphoras (C 9489 and C 9504) were found in the same stratum, a short distance to the west and to the east, just above the LM I plaster floor. The stratum immediately above the anchors was later, including fragments of short-necked amphoras, which typify the LM IIIA2/IIIB floor accumulations within Building P. The latter date indicates the time after which the anchors had gone out of use as bases. The period when the anchors were abandoned at the harbour of Kommos could be much earlier, prior to the remodelling of the plaster floor of Building T in LM IIIA.

\section{Catalogue of the Kommos Anchors}

1. S 2233 (Figs 1-3c, Table 1). Trench 89A/ Pail 6, Surface 2. LM IIIA1.

Maximum length: 0.665 m. Maximum width: $0.57 \mathrm{~m}$. Maximum thickness: $0 \cdot 165 \mathrm{~m}$. Actual weight: $74 \mathrm{~kg}^{[2]}$.

A roughly triangular limestone slab with rounded top and bottom, pierced by three roughly rounded holes. It is complete. The slab was produced by natural cleavage and then fashioned to present shape. The rounded top and bottom appear to be intentional. All three holes (the largest is $0.10 \mathrm{~m}$ in diameter) were probably cut by a chisel. As is the case with the second anchor, there is no evidence,

(C) 1995 The Nautical Archaeology Society 


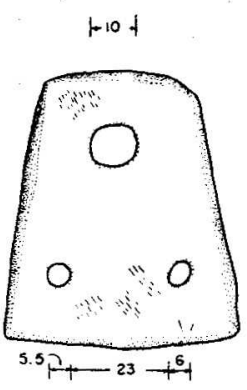

FACE I

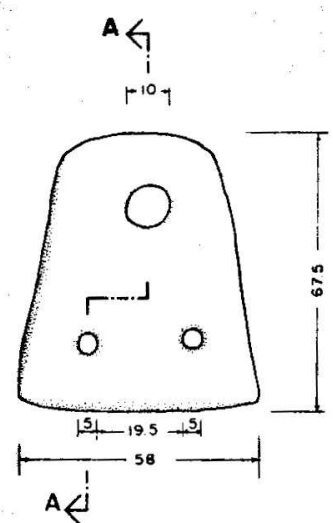

FACE 2

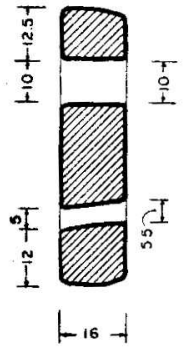

SECTION A-A

ANCHOR S2233 WEIGHT:74 KLLOGRAMS
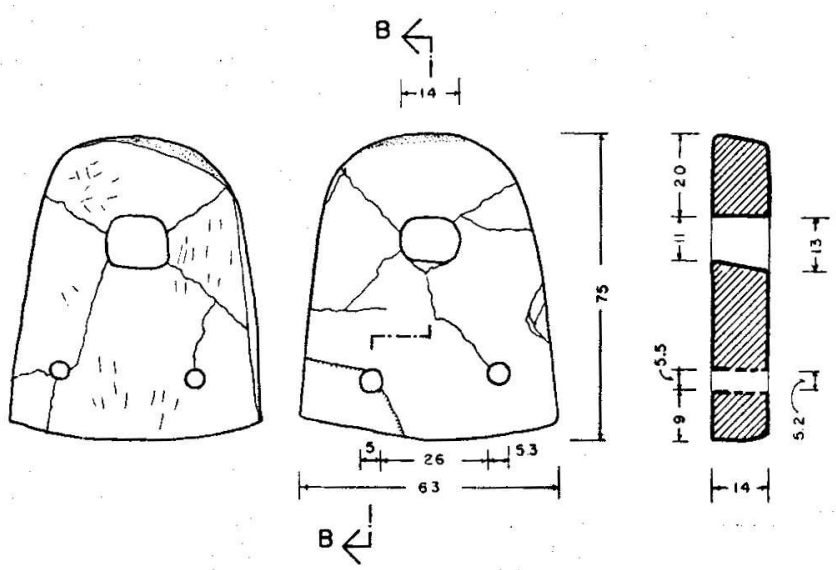

FACE I

FACE 2

SECTION B-B

ANCHOR S2234 WEIGHT: 75 KILOGRAMS

KOMMOS

Tivilava $20 \quad 30 \quad 40 \quad 50 \mathrm{~cm}$

Figure 1. Anchors S 2233 and S 2234 from Kommos. (Drawing: Giuliana Bianco.)

such as circular scorings, to show that any of the holes were drilled, as was often the case in the Levant (Frost, 1975: 388). One of the smaller holes was cut. perhaps unintentionally, at an angle. Below the smaller hole there is a mark, likely to be accidental ${ }^{[3]}$.

The stone was identified by Andrew D. Miall as a pale buff-brown foraminiferal limestone. He comments that:

'Faint stratification is generated by variations in mud or dust content of $t$ the limestone, and broken shells are aligned parallel to bedding. Petrographically the limestone is a packstone, consisting of fairly densely packed foram tests with rare crinoid stem fragments and bryozoans, and few other components, set in a micritic matrix. Foram tests average about $0.25 \mathrm{~mm}$ in diameter. Many tests are empty, giving the limestone a porosity o about $25 \%$ There appears to have been virtually no recrystalization, and there is no dolomitization.'

2. S 2234 (Figs 1, 2, 4a \& 4b, Table 1). Trench 89A/Pails 6, 93, Surface 2. LM IIIA1.

Maximum length: $0.72 \mathrm{~m}$. Maximum width: $0.613 \mathrm{~m}$. Maximum thickness: $0 \cdot 145 \mathrm{~m}$. Actual weight: $75 \mathrm{~kg}$. 


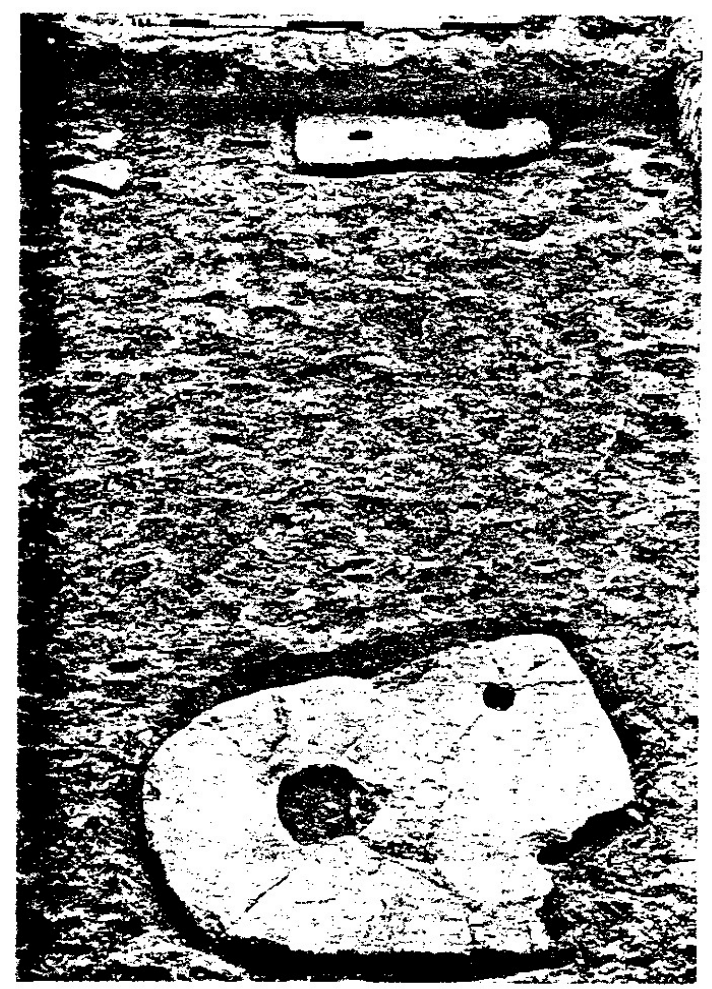

Figure 2. Anchors S 2234 (foreground) and S 2233 (background) as found. (Photo: J. W. Shaw.)

A roughly triangular slab of limestone with rounded bottom edge like S 2233 and with three holes, the largest of which is roughly rectangular but with rounded corners like another anchor, S 636 (Fig. 5), found on the Kommos hillside in a mixed context (Shaw \& Blitzer 1983). The squarish rope hole on an anchor is sometimes thought to reflect local style. and hence origin (McCaslin, 1980: 66). A possible hint of local preference may be the curving bottoms of the two Kommos anchors. In both, the curves, as seen in the plans in Fig. 1, are fairly regular and do not appear to be the result of wear. Since each anchor has a similar curve, it is probable that the arcs were intended. Technically, they could be the result of an arc cut by chisels on the surface of a stone quarry before removal of the anchor blocks. The arc at the bottom of $\mathrm{S}$ 2233, as seen in plan, can be roughly duplicated if a radius is drawn from about 1.23 $\mathrm{m}$ on the midline of the anchor (that is, the midline of the anchor extended vertically over the main rope hole and beyond the anchor itself, as in Fig. 6). For S 2234, a similar radius is about $1.13 \mathrm{~m} \mathrm{long}^{[4]}$.

The top is carefully rounded by pecking. No tool marks apparent on either face. The natural limestone layering is less consolidated than that of S 2233, and when found was missing part of a corner, lost during antiquity (Fig. 4a). This same tendency to fracture was noted when it was removed from the site, for some of its lower part flaked off into small slabs. The anchor had cracked into at least five pieces in re-use, perhaps due to the weight of a post set upon it.

The limestone does not match exactly any of the samples of limestone selected from the Kommos area but is nevertheless of a common type, according to John A. Gifford (pers. comm.), who recently published an analysis of the geology of Kommos (Gifford, 1995). Theoretically, it could occur somewhere in the Kommos region. Brooks Ellwood thinks that this anchor could have come from a different part of the same quarry, from which the other anchor was extracted. Andrew Miall noted that the stone is similar to that of the first anchor, but 'stratification is not visible. There are scattered rare grains of glauconite and limonite, and rare quartz grains (fine sand size).'

\section{Discussion}

The discovery of the two new anchors brings the number of those found at Kommos, including one in the sea, to eight (Shaw \& Blitzer, 1983: Shaw, 1984: 286 and pl. 60e). Six others are published or reported from elsewhere in definite Middle and Late Bronze Age Aegean contexts and, interestingly, include one (an irregular boulder) found in a town square in the LC IA settlement at Akrotiri, Thera (Marinatos, 1974: pl. 29) ${ }^{[5]}$. Apart from the new Kommos anchors, those from Crete all appear to be of the triangular type with a single hole pierced near the smaller end. That from Makriyialos, of which only the upper part with the rope hole is preserved, is associated by its discoverer with a tradition of sacred anchors (Davaras, 1980). 
(a)

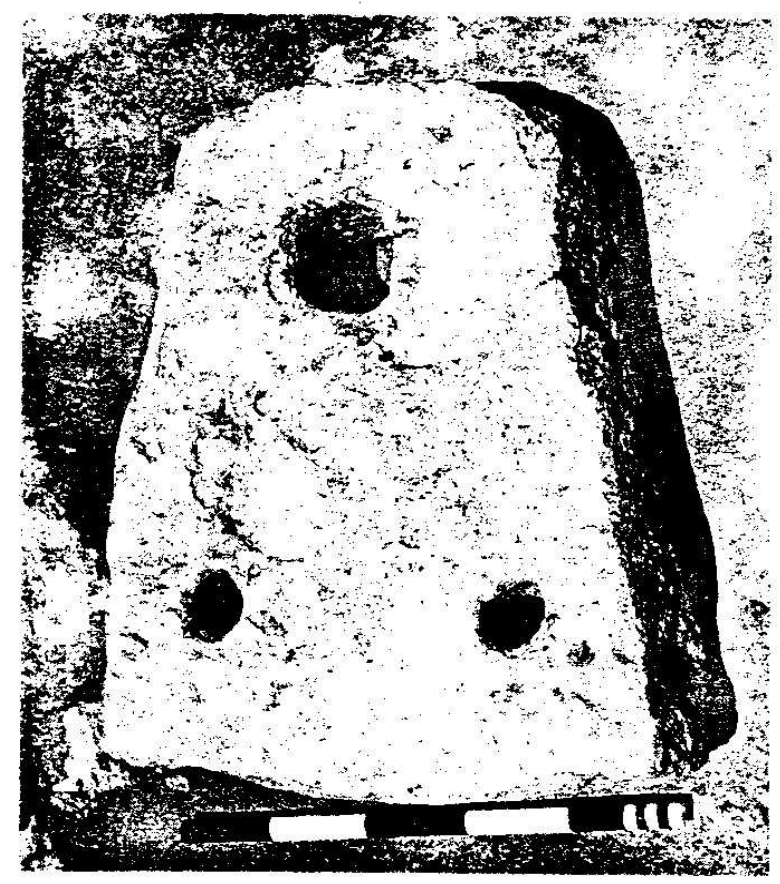

(c)

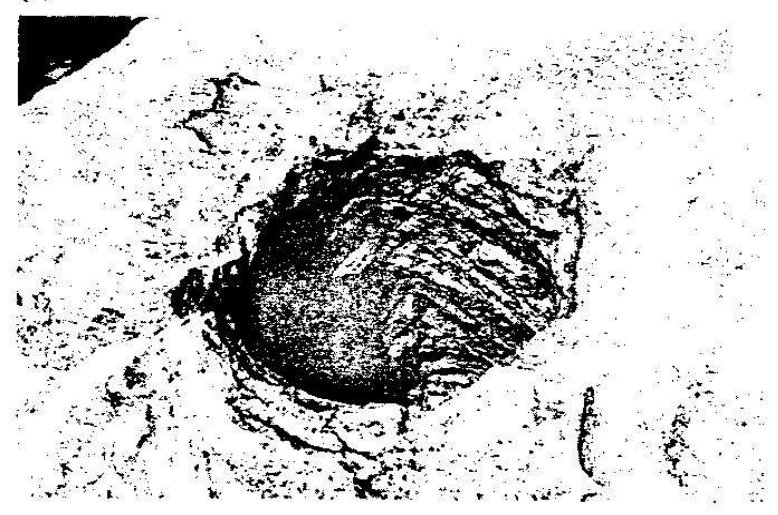

(b)

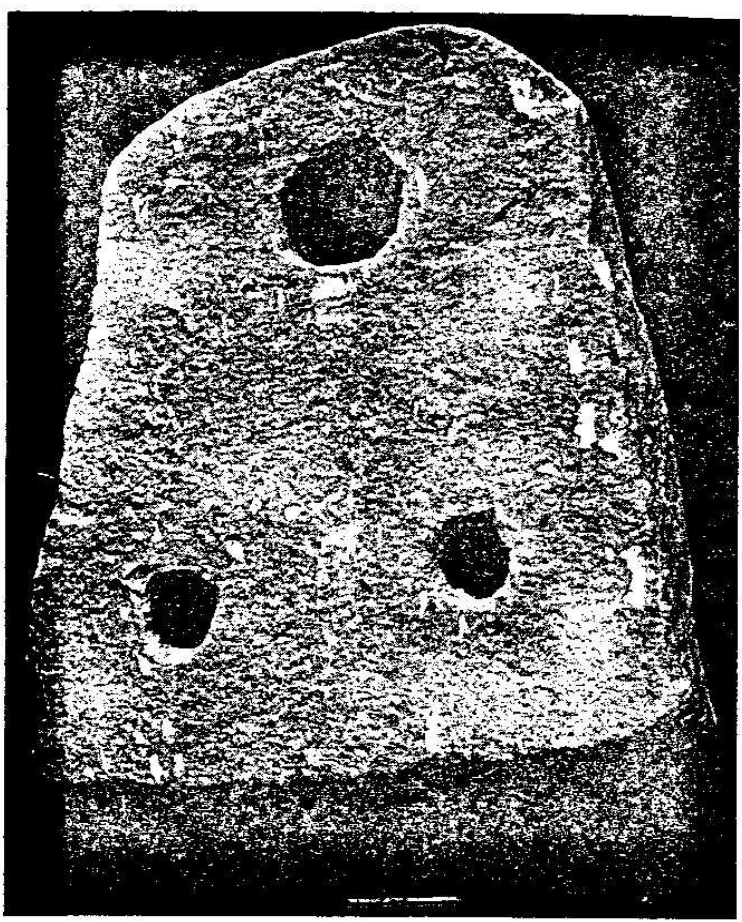

Figure 3. Anchor S 2233: (a) upper face (Side 1), as found (Photo: J. W. Shaw): (b) Face 2 (Photo: T. Dabney), and (c) detail of one of the smaller holes showing tool marks (Photo: A. Perron.)

61-67 and McCaslin, 1980: 33) Alternatively, it may also have had a religious function (Shaw \& Blitzer, 1983: 92) ${ }^{[7]}$.

The importance of the two new anchors from Kommos is that they are the first of their typo to be found on Crete ${ }^{[8]}$. In addition to the large hole for the anchor rope. two smaller hole (44-62 $\mathrm{mm}$ in diameter) are pierced through their lower part. As suggested in Fig. 7, the holes were probably for the insertion of pointed, perhaps curving, wooden stakes that functioned like the flukes of a metal anchor to hold the anchor to the sea 


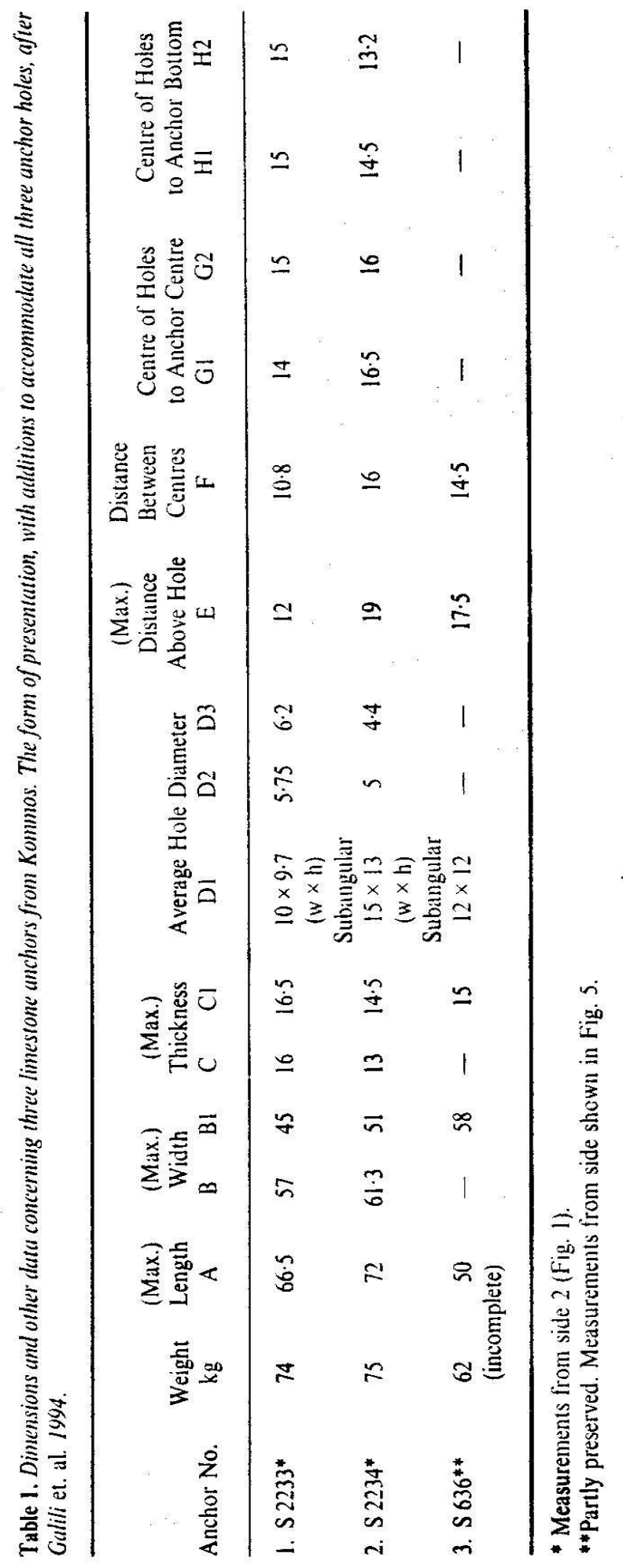


(a)

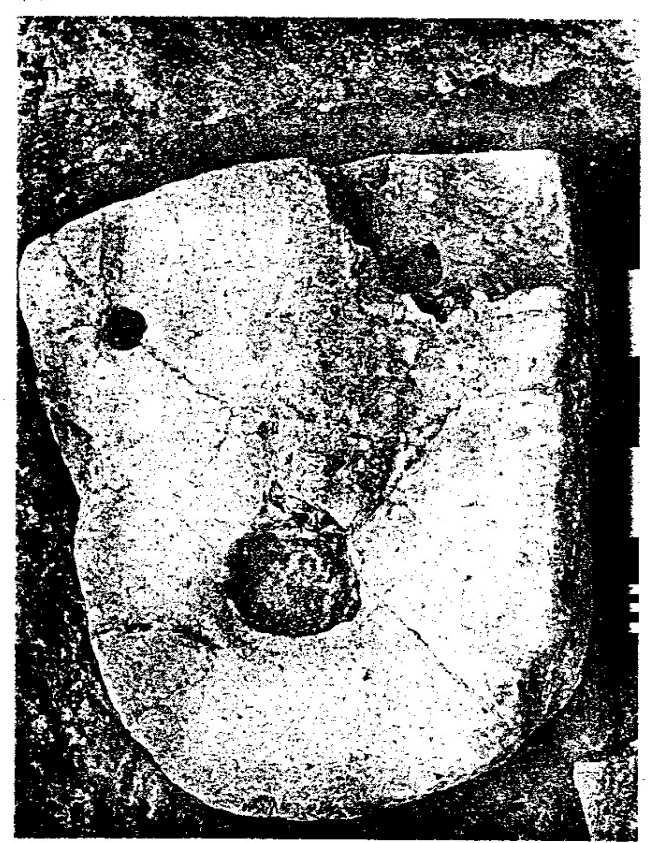

(b)

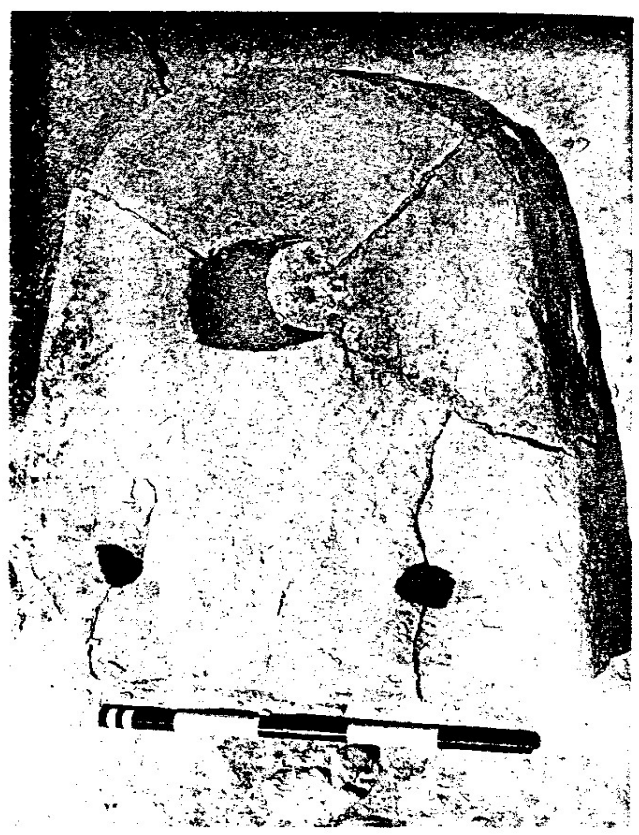

Figure 4. Anchor S 2234: (a) upper side (Face 2), as found; and (b) Face 1 before consolidation. (Photos: J. W. Shaw.)

bottom $^{[9]}$. Furthermore, the Kommos anchors are among the few of their type from a definable chronological context. Their association with Levantine and Cypriot pottery also lends further support to the idea, originally suggested by the relatively high frequency of imported sherds in contexts of that date at Kommos, of greater contact with foreign lands in LM IIIA (Shaw \& Blitzer 1983: Watrous, 1992: 174).

While rare in the Aegean, such threeholed of composite anchors are well known east of the Aegean, especially at coastal Ugarit (modern Ras Shamra) in Syria, and at Kition and Hala Sultan Tekke in Late Bronze Age Cyprus ${ }^{[10]}$. The following list provides an idea of the numbers and geographical distribution of composite anchors in the Mediterranean, based on reported examples:

$\begin{array}{lc}\text { Syria-Palestine } & 28 \text { (Ugarit 10, Athlit 18) } \\ \text { Egypt } & 1 \text { (Karnak) } \\ & 38 \text { (Kition 24, Hala } \\ & \text { Sultan Tekke 5, } \\ & \text { Capes Andreas, } \\ \text { Cyprus } & \text { Kiti, and Greco 9) }\end{array}$

$\begin{array}{ll}\text { Cyclades } & 1 \text { (Mykonos museum) } \\ \text { Mainland Greece } & 1 \text { (Cape Iria wreck) } \\ \text { Crete } & 2 \text { (Kommos) } \\ & 4 \text { (Adriatic coast 2, } \\ \text { Italy } & \text { Salerno 1, near } \\ & \text { Tiber 1) } \\ \text { France } & 1 \text { (Marseille) }\end{array}$

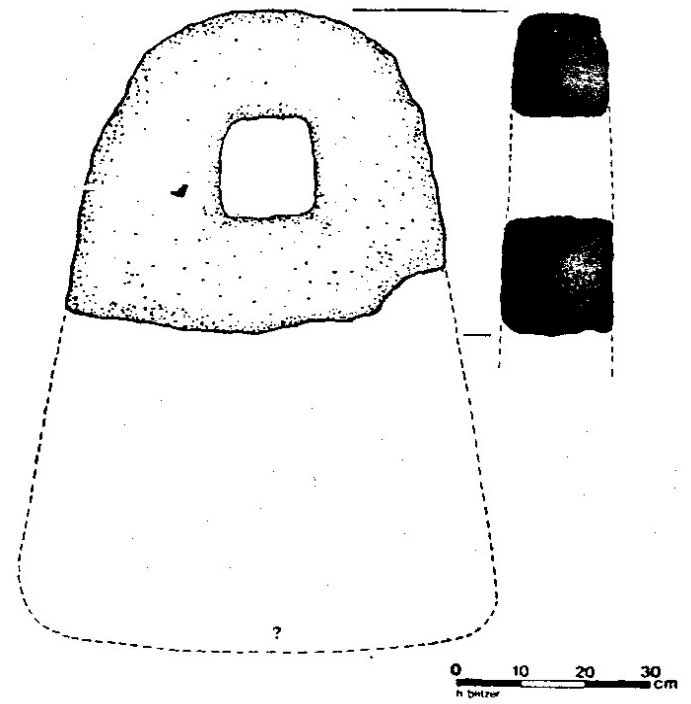

Figure 5. Anchor S636 restored (Drawing: Harriet Blitzer.) 


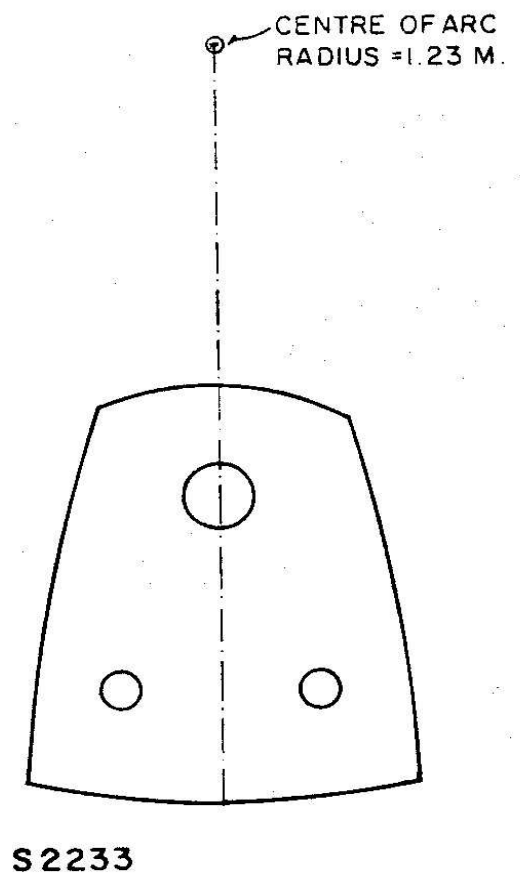

Figure 6. Diagram indicating approximate curve of bottom face of C 2233 from Kommos. (G. Bianco.)

(7)
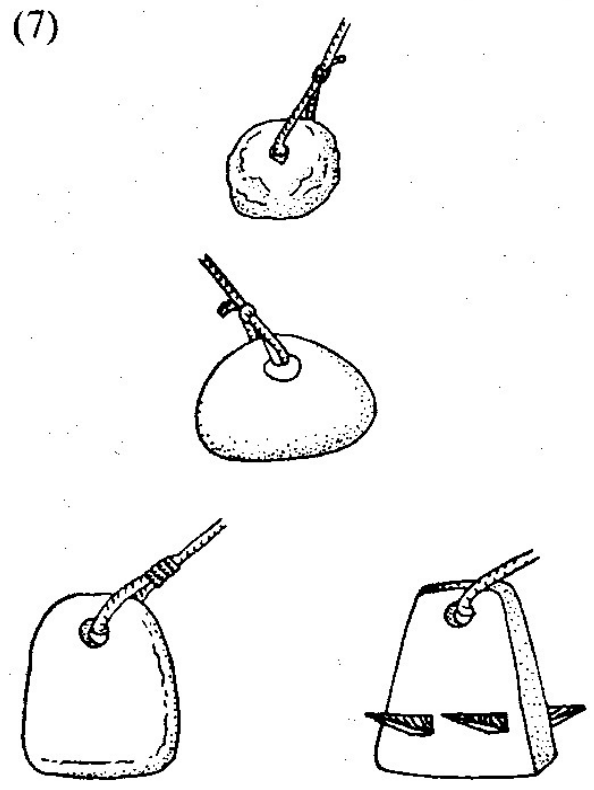

(8)

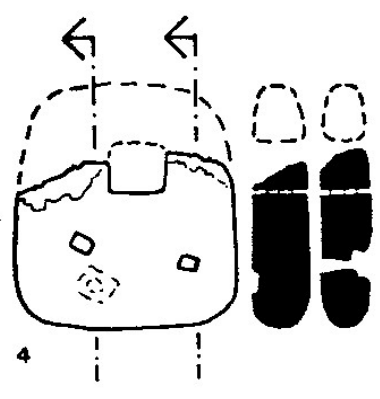

UGARIT
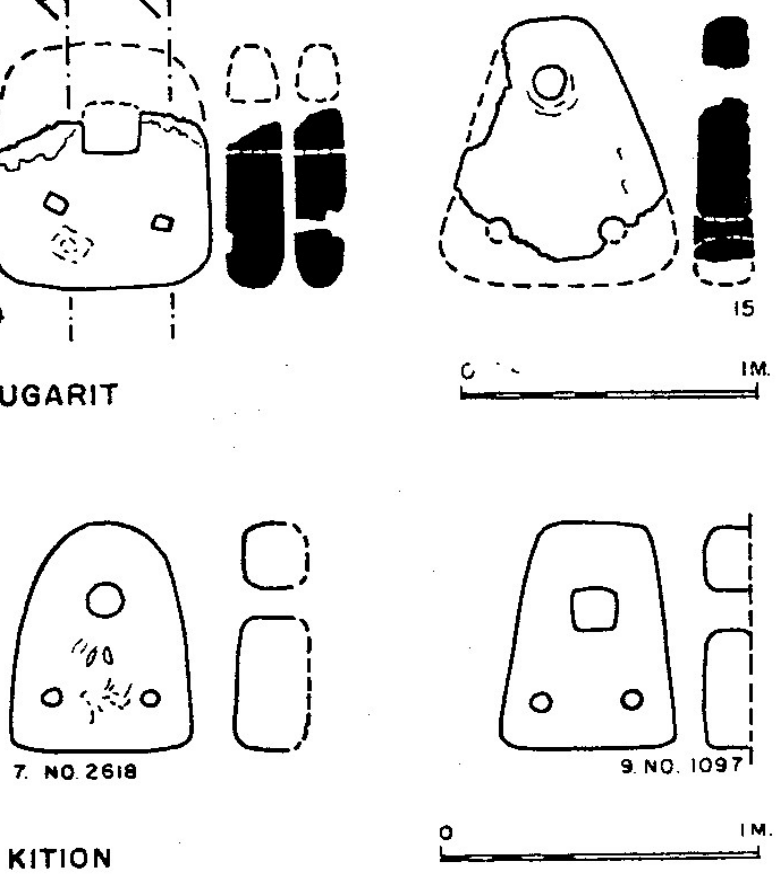

Figure 7. Diagram illustrating stone anchors. (Adapted from Kapitän, 1984.)

Figure 8. Top: Ugarit anchors nos 6 and 7 (after Frost, 1991). Bottom: Kition anchors nos 2618 and 1097 (after Frost, 1985). (Drawing: Giuliana Bianco.) 


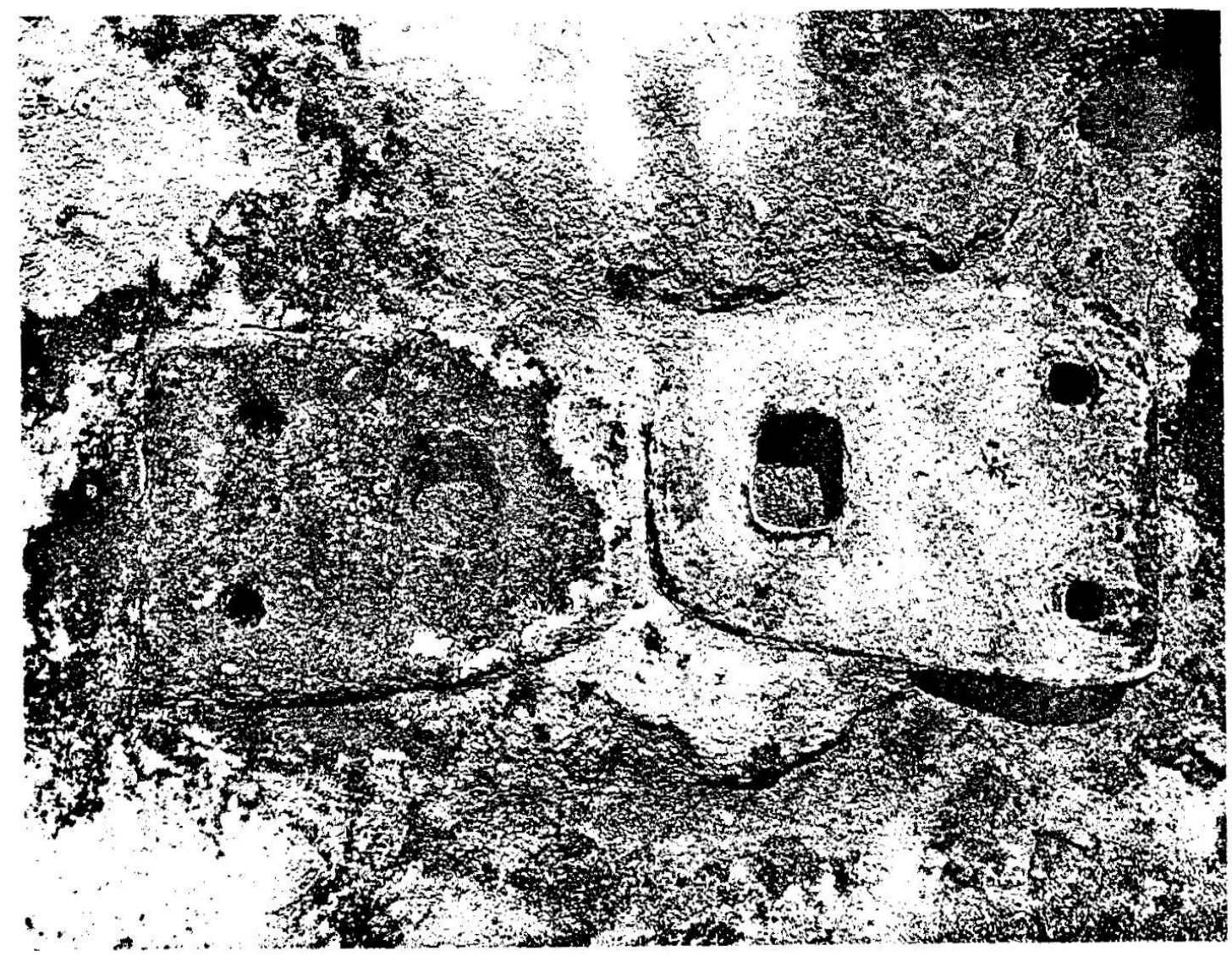

Figure 9. Kition anchors nos 4972 and 4973 in situ, set in a pit cut in the bedrock in Room 24A, possibly for Floor IV of Temple 2, LC IIIA (Courtesy Vassos Karageorghis.)

On the other hand, three-holed anchors were particularly popular in Cyprus, and it is tempting to suggest that the two Kommos anchors, found associated also with Cypriot pottery, are from Cyprus and were brought and left at Kommos either by Minoan or Cypriot traders ${ }^{[13]}$. Of the more than one hundred Late Bronze Age and Phoenician anchors from Kition (Frost. 1985), at least 18 of those illustrated in publications are of the three-holed type and are from Late Bronze Age context. Some of them are close parallels to the Kommian anchors. Compare for instance the sizes of four anchors from Kition (Figs 8 \& 9) with the Kommos examples (Table 2) ${ }^{[14]}$. The presence of a Cypro-Minoan sign on Kition no, 2618 may identify the undated anchor Cypriot $^{[15]}$.

For the Kommian anchors to be plausibly connected with Cyprus, however,
Table 2. Comparative sizes of anchors from Kommos and Kition (in $\mathrm{cm}$ )

\begin{tabular}{llll}
\hline & Length & Width & Thickness \\
\hline Kommos 2233 & $66 \cdot 5$ & 57 & $16 \cdot 5$ \\
Kommos 2234 & 72 & $61 \cdot 3$ & $14 \cdot 5$ \\
Kition 1097 & 73 & 56 & 14 \\
Kition 2618 & 75 & 58 & 25 \\
Kition 4972 & 73 & 49 & 14 \\
Kition 4973 & 72 & 49 & $11-14$ \\
\hline
\end{tabular}

the tradition of three-holed anchors in Cyprus should shown to be at least as early as LM IIIA1 (1390/1370-1370/1360 BC; dates from Warren and Hankey, 1989: 169 and table 3.1), The earliest context for the positioning of those Kition, usually within the temples, is LC IIIA, about 1230-1190 BC or somewhat later, at least 130 years after S 2233 and S 2234 from Kommos were set in place (Buchholz \& 


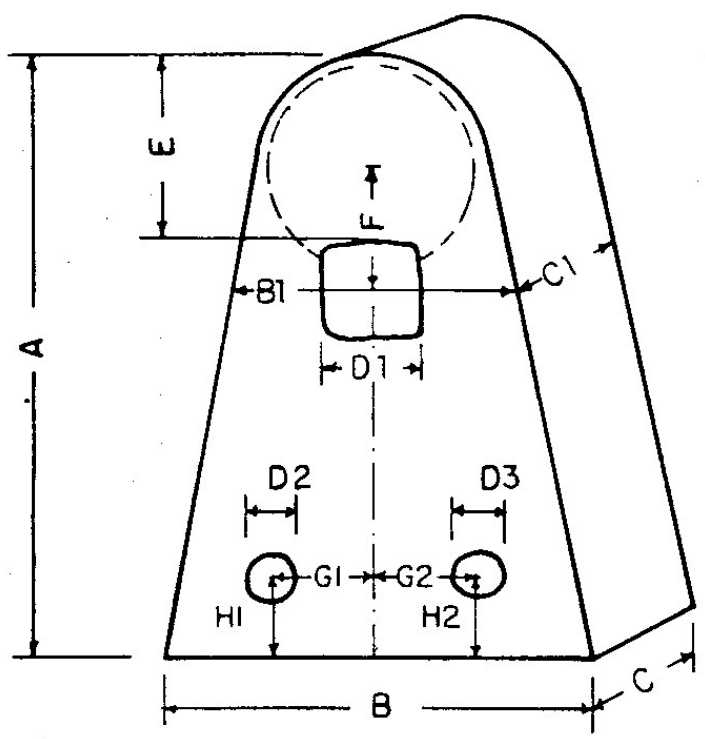

Figure 10. Anchor dimensions (after Galili et. al., 1994: fig. 17, with additions to accommodate all three anchor holes). $A=$ maximum height; $\mathrm{B}=$ maximum width at lower part; $\mathrm{B} 1=$ maximum width at hole centre; $\mathrm{C}=$ maximum thickness at lower part; $\mathrm{Cl}=$ maximum thickness at hole centre; D1, D2, $\mathrm{D} 3=$ average hole diameters; $\mathrm{E}=$ distance from hole to top of anchor; $F=$ distance between apex centre and hole centre: Gl, $G 2=$ distance from centre of lower hole to anchor's vertical axis; $\mathrm{H} 1, \mathrm{H} 2=$ distance from centre of lower hole to anchor's bottom.

Karageorghis. 1973: 138; Frost, 1985: 295ff.; Merrillees, 1992: 51 ${ }^{[16]}$. Possibly the earliest be Cypriot anchors are from Hala Sultan Tekke, for they fall somewhere within the range of the 17th to the 13th century BC (Frost, 1970: 14).

Can the geological character of the stone of at the anchors help to determine the geographical area where they were quarried? Andrew Miall at compared microphotographs of their stone (Fig. 11) with those published by Frost from Ugarit (Frost. 1991: pls XIIIXIV) and Kition (Frost, 1985: pls K-N). He noted that while the limestones making up the two Kommos anchors are very similar to one another, they are

'not much like the photographed samples in the two publications. It is possible, however, that they could have come from the same location as the samples from Ugarit identified by numbers 11,15 , and 34 in Frost (1991). although detailed examination of those samples themselves might generate a different opinion. Limestones can vary in petrographic character considerably within a few centimetres of bed thickness.'

Miall, therefore, finds possible parallels with Ugarit rather than with Cyprus.

As we have seen, a lack of consistency in the geological make-up of limestone within a single quarry presents an obstacle to secure identification of provenance. Also, similar sediments/rock type of equivalent age are widely distributed over large areas of the Mediterranean. Another means of investigating provenance, however, lies in the identification of the microfossils present in the stone. The identification determines the geological age of the stone which, in turn, can be compared with the geological make-up of certain geographical areas. William A. Berggren and Marie-Pierre Aubry examined samples prepared from the Kommos anchor stones, and concluded that they are of an early Miocene age. They comment:

Sample S 2233: calcareous nannoplankton are extremely rare and include Sphenolithus neoabies, Coronocyclus nitiscens, Coccolithus miopelagicus, Reticulofenestra floridana, Helicosphaera mediterraneana, and Triquetrorhabdulus milowi; planktonic foraminifera include Globigerinoides and globular tests of (supposed) globigerinides indeterminate taxa. Sample S 2234: calcareous nannoplankton arc abundant and include (in addition to large numbers of reworked forms from the Eocene and Oligocene) Coccolithus miopelagicus, Retucolofenestra bisects, $R$. floridana, Sphenolithus neoabies, S. sp. cf. $S$. delphix, Coronocyclus nitiscens, Helicosphaera carteri. $H$. intermedia, Triquetrorahabdulus milowi and $T$. carinatus. These assemblages are indicative of early Miocene and probably assignable to zone NN2 (Aquitanian to early Burdigalian Age), The complete absence among the planktonic foraminifera of any representation of the genus Orbulina, which is a common component of Mediterranean stratigraphies beginning in the early Miocene (Langhian Stage) supports the early Miocene age based on calcareous nannoplankton. 


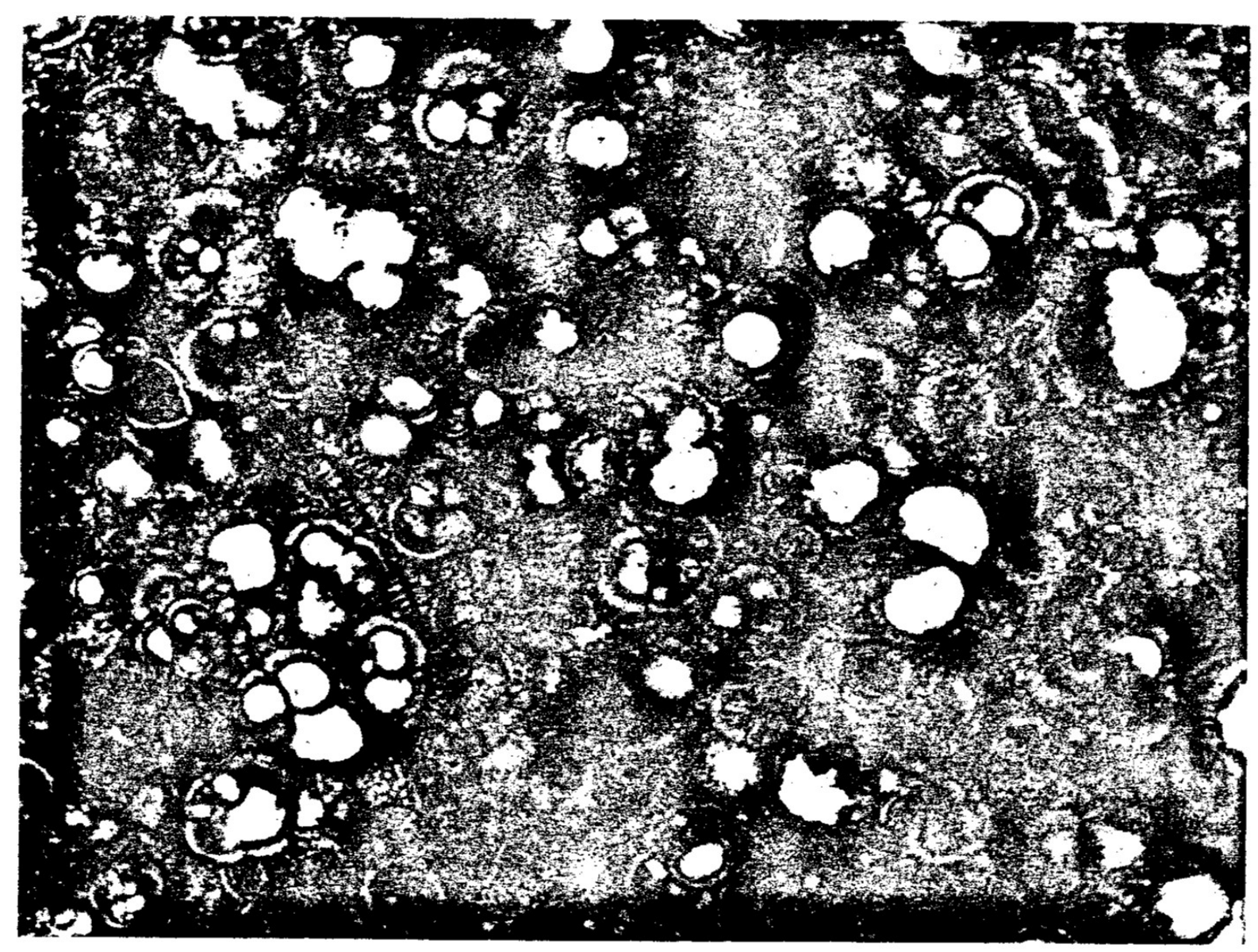

Figure 11(a).

They also determined that the stone of the anchors best fits that of Cyprus, Malta, or Coastal Syria, north and south of modern Latakia which is just south of Ugarit ${ }^{[17]}$. Of particular interest in narrowing the possibility of provenance for the Kommos anchors is that Crete can apparently be eliminated because the anchor stone. with calcareous nannofossils, is of early Miocene age, whereas carbonate deposition did not begin on Crete until later, during the Middle Miocene ${ }^{[18]}$.

Once Malta, which is an unlikely provenance for the anchors ${ }^{[19]}$, and Crete are omitted, Cyprus and Syria (probably Ugarit) become the likely geological sources for the Kommos anchors' stone. Corroborative evidence is provided by the anchor typology that points to these areas and by the imported pottery found in direct association with the anchors.
What do the Kommian anchors tell to about the ships that may have earned them? The best evidence comes from the Ulu Burin merchant vessel, perhaps about 13-14 m long and $4.5 \mathrm{~m}$ wide (G. Bass, after C. Pulak, letter of 1/4/93). This is the only example to date of a prehistoric wreck with its cargo largely intact Bass et al. 1989). The ship carried at least 24 anchors, most of sandstone, all with a single hole. Eight were carried in the centre of the hull; 16 were in the bow (Wachsmann, in press). If the number seems excessive, it may have been expected that some anchors would be lost during a voyage. On the other hand, it is reasonable to suggest that some were carried by the ship as items for trade. Six of the larger ones were weighed and were found to vary between 121 and $210 \mathrm{~kg}$ (Pulak, pers. comm. 24/7/93). There are two smaller ones in the $20 \mathrm{~kg}$ range, with the remainder falling 


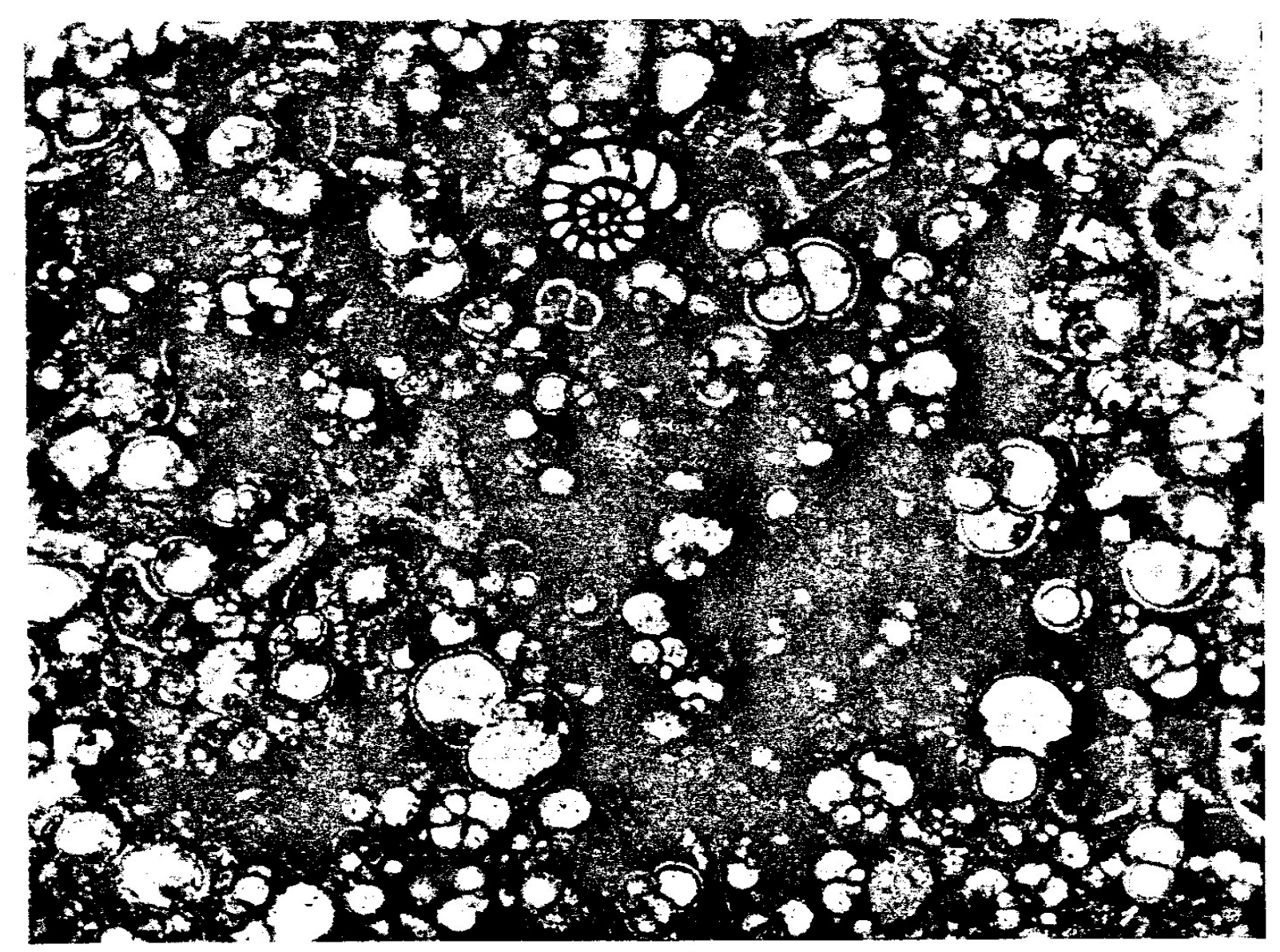

Figure 11(b).

Figure 11. The stone of anchors S 2233 (a) and S 2234 (b), X2. (Photo courtesy B. Ellwood and M. Nestell.)

within these two main groupings. The Kommos anchors, about $75 \mathrm{~kg}$ each, would anchors being carried by this single ship, it can only be suggested that the Kommos anchors were probably originally intended to form part of group being carried for use at sea. Like those carried by the Ulu Burun ship, they wool probably be selected for use by the crew in terms of prevailing water depth, relative speed of current, wind factors, and bottom type. It also possible that the two unworn anchors wet left at Kommos as the result of a commercial exchange.

\section{Acknowledgments}

For their help, the author is indebted to Honor Frost, Dr Vassos Karageorghis, Dr Charalambos Kritsas and Drs George Bass, Cemal Pulak and Shelley Wachsmann from the Institute for Nautical Archaeology. belong in this middle category. Given the actual range of the weight of individual

Geological expertise was provided by Professors Brooks Ellwood (University of Texas at Arlington), John Gifford (University of Miami) and Andrew Miall (University of Toronto), as well as Drs William A. Berggren (Woods Hole Oceanographic Institution), Marie-Pierre Aubry (Institut des Sciences de (l'Evolution, University of Montpelier, France), Fritz F. Steininger (University of Vienna) and Fred Rögl (Naturhistorische Museum, Vienna). Gordon Nixon (University of Toronto) excavated the anchors and Barbara Hamann (Oriental Institute) reconstituted S 2234, discovered broken. Professors Jeremy Rutter (Dartmouth College) and Maria C. Shaw (University of Toronto) commented on drafts of the article. 


\section{Notes}

[1] For the most recent report and references to earlier reports, see Shaw \& Shaw, 1993.

[2] It is important that anchors are actually weighed, where possible, for weights based solely on stone type and cubic content can be erroneous. The two Kommos anchors weigh about $75 \mathrm{~kg}$ each. Using the weight estimation method suggested by Frost, S 2233 would have weighed 142.4 $\mathrm{kg}$ and S 2234 would have weighed $155.8 \mathrm{~kg}$, (calculated by Gordon Nixon). It was inspected by Eric Hallager, knowledgeable in Linear scripts, who did not find it to be significant.

[4] There are few parallels. Curving bottoms are visible, however, on published examples from Ugarit (Frost, 1991: plate III, 5 and plate IV, 7 ) and from Kition (Frost, 1985: fig. 8.7 No. 4978 and fig. 9.9 No. 51181. No. 4978 from Kition, a composite anchor of conglomerate, probably provides the closest parallel since in plan its bottom profile is a fairly regular curve and in section the anchor bottom is not rounded, like S 2234.

[5] Harriet Blitzer recently decided that some of the holed stones published earlier as anchors from Kommos (Shaw \& Blitzer, 1983) may in fact be weights used in olive presses (Blitzer, 1995). However, anchors could have been brought to land and re-used as weights, or as building materials as is the case with the two three-holed anchors presently under consideration. Another pierced stone, originally published as an anchor, is from Petras in eastern Crete (Tsipopoulou, 1989). Ms Tsipopoulou now thinks that since it is so light $(8.6 \mathrm{~kg})$ it probably served some other purpose (pers. comm. 15/2/94). For recent surveys of Aegean anchors, see Nibbi, 1993: 12-15; also Wachsmann, in press. A similar Aegean anchor, as pointed out to me by Shelley Wachsmann, is of unknown provenance in the Aegean Maritime Museum at Mykonos, illustrated in Motion, Olympic Airways Magazine, May 1990: 82. Another was located underwater in 1974 in the vicinity of the Late Bronze Age wreck (c. 1200 BC) near Cape Iria southeast of Nauplion (Pennas \& Lolos, 1991: 16). Charalambos Pennas and Yannis Vichos have kindly provided information that this anchor, still under study, is quite different from the Kommos examples, being smaller $(0.48 \mathrm{~m}$ x $0.405 \mathrm{~m}$ x $0.075 \mathrm{~m}$ ) and much lighter $(25 \mathrm{~kg}$ versus $74-75 \mathrm{~kg}$ ). It is of hard conglomerate rather than the more usual limestone. In addition, the three holes are of the same diameter $(0.04 \mathrm{~m})$; usually in such anchors the upper hole is considerably larger than the two toward the lower part of the anchor. It also appears that the anchor cannot be dated with safety to the Late Bronze Age despite its position within the context of the wreck. Yannos Lolos, responsible for the publication of the pottery finds from the wreck, notes that the wreck contains Late Cypriot IIC/IIIA pithoi and jugs and LH IIIB2/LM IIIB2 vases, including six coarse-ware stirrup jars probably of Cretan provenance (pers. comm. 19/1/94).

Frost notes that fishermen in Syria prefer the composite stone anchor type to the modern metal ones, since if the wooden flukes get stuck on the bottom, they can simply be broken off by pulling hard enough on the anchor rope (Frost, 1975: 393). Another possibility, suggested by Nibbi (1993: 10, fig. 8a) is that the additional holes could have served to secure the heavy anchor if it were on the side of the vessel.

[10] Nibbi has reviewed the chronology and variety of stone anchors, of which perhaps the earliest is from Egypt, and datable to no later than c. 2345 BC (Nibbi, 1993: 11). Usually, stone anchors, which continued in use after the Bronze Age, have a single hole. The three-holed type was used concurrently with single-holed anchors. There are no composite examples from Bronze Age Byblos and only one from Egypt, a Kition-type possibly dedicated there by Cypriots but apparently made of local stone (McCaslin, 1990: 35; Frost, 1991: 371). Undated examples are reported from Italy (the Adriatic coast, Salerno, and near the mouth of the Tiber) and France (near Marseilles; Nibbi, 1993: 17).

[11] Schaeffer, 1978: 375. See also Frost 1969a: 242; 1991: 367-368, 377-378; Nibbi, 1993: 12.

[12] A. Raban (1988: 285-288) has suggested that composite anchors were invented by the Sea Peoples during the 13th century BC. However, the probable earlier contexts for the Ugaritic 
composite anchors, and the definite LM IIIA1 (first half of the 14th century BC) context for the two Kommos anchors being published here make this theory unlikely.

[13] McCaslin suggests that Cypriot or Cypro-Syrian ships carried out much of the east-west trade (1980: 119). Nibbi made a similar suggestion about Kommos in particular (1993: 13). However, Frost (1991: 370; 1993: 453) has commented that the relatively light weight of the anchors described by Shaw \& Blitzer (1983), as well as the fact that they could be of local stone, suggest local craft or even fishermen's weights, apart from S 636 (Fig. 5) which could have anchored the larger seagoing craft. The two new Kommos anchors would tend to strengthen the case for international connections, at least for the transitional period between the desertion of Building $\mathrm{T}$ and the construction of Building P. For P's possible use for storing ships, which would therefore probably be Cretan, see M. Shaw, 1985; also Shaw \& Shaw, 1993: 188.

[14] For the Kition examples: Frost 1985: 295 and pl. A(6) for 4972-4973; 296 and pl. A(7) for 2618; 311 and pl. 11(9) for 1097.

[15] As to the sign on the anchor, Jeremy Rutter has noted (pers. comm. 4/12/1993) that Cypriots frequently marked non-Cypriot items such as Mycenaean and Levantine transport containers with Cypro-Minoan countermarks.

[16] Honor Frost, who initiated the study of ancient stone anchors, has published with care those from Ugarit (1969 $\alpha$; 1991), Byblos (1969b), and Kition (1985), and helped establish a working typology (Frost, 1973; 1975, 1991). Others, especially McCaslin (1980) and Nibbi (most recently, 1993), have discussed and added new examples to the growing corpus. Steininger et al., 1985: I, 34-38, 50-51; II, 117-120, 123-125, 197, 200, 315.

[18] A more comprehensive study of anchor stone provenance, or for that matter the provenance of fossiliferous limestone suspected of being imported, might be initiated. This would be based on fossil evidence from the anchors themselves together with building stone from related sites.

Malta does not have a known contemporary tradition of pierced stone anchors, nor was it as closely connected with Aegean trade routes as were Cyprus and Syria. However, at Kommos during LM IIIA1 there appears the first evidence for interconnections with Italy, and with Sardinia in particular, but with no evidence as yet for Malta (Watrous, 1992: 163).

\section{References}

Bass, G. F., Pulak, C., Collon, D. \& Weinstein, J. 1989, The Bronze Age shipwreck at Ulu Burun, 1986 campaign, $A J A$, 93: 1-29.

Blitzer, H., 1995, Minoan implements and industries. In: Shaw, J. W. \& Shaw, M. C. (Eds), Kommos, I: The Kommos Region and Houses of the Minoan Town. Part 1, The Kommos Region, Ecology, and Minoan Industries. Chapter 8. Princeton.

Buchholz, H.-G. \& Karageorghis, V., 1973, Prehistoric Greece and Cyprus: An Archaeological Handbook. London.

Davaras, C., 1980, Une ancre minoenne sacrée? BCH, 104: 47-71.

Evans, Sir A., 1935, The Palace of Minos at Knossos, IV. London.

Frost, H., 1969 $\alpha$, The stone-anchors of Ugarit. Ugaritica, XVII: 235-244.

Frost, H., 1969b, The stone-anchors of Byblos. Mélanges de l'université Saint-Joseph, XLV: 425-442. Beirut.

Frost, H., 1970, Some Cypriot stone-anchors from land sites and from the sea. RDAC, 14-24.

Frost, H., 1973, Anchors, the potsherds of marine archaeology: on the recording of pierced stones from the Mediterranean. In: Blackman, D. (Ed.), Marine Archaeology, 397-409. London.

Frost, H., 1975, Bronze Age stone-anchors from the Eastern Mediterranean, dating and identification. Mariner's Mirror, 61: 377-394.

Frost, H., 1985, The Kition anchors. In: Karageorghis, V. \& Demas, M. (Eds), Excavations at Kition, V, The Pre-Phoenician Levels (Areas I and II), Part I, Appendix I: 281-321. Nicosia.

Frost, H., 1991, Anchors sacred and profane; Ugarit-Ras Shamra, 1986; the stone anchors revised and 
compared. In Yon, M. (Ed.), Ras Shamra-Ougarit, VI: Arts et Industries de la pierre. 355-410. ERC Paris.

Frost, H., 1993, Stone anchors: a reassessment reassessed. Mariner's Mirror, 79: 449-458.

Galili, E., Sharvit, J. \& Artzy, M., 1994. Reconsidering Byblian and Egyptian stone anchors using numeral methods: new finds from the Israeli coast. IJNA, 23: 93-107.

Gifford, J., 1995, The Physical Geology of the Western Mesara and Kommos. In: Shaw, J. W. \& Shaw, M. C. (Eds), Kommos I, Part 1, The Kommos Region, Ecology and Minoan Industries. 30-90. Princeton.

Kapitän, G., 1984, Ancient anchors-technology and classification. IJNA, 13: 33-44.

Marinatos, S., 1974. Excavations at Thera, VI (1972 Season). Athens.

McCaslin, D. E., 1980, Stone anchors in antiquity: coastal settlements and maritime trade-routes in the Eastern Mediterranean ca. 1600-1050 B.C., SIMA, 61. Göteborg.

Merrillees, R. S., 1992, The absolute chronology of the Bronze Age in Cyprus: a revision. BASOR, 288: 47-52.

Nibbi, A., 1993, Stone anchors: the evidence re-assessed. Mariner's Mirror, 79: 5-26.

Pelon, O., 1970, Fouilles exécutées a Mallia (III), le Quartier E (1963-1966), Études Crétoises, 16.

Pennas, Ch. \& Lolos, I., 1991, Underwater surface exploration at the wreck of Late Bronze Age period at the Peninsula of Iria. Enalia, III: 8-25.

Poursat, J.-C., 1980, Les ancres du Quartier Mu, Fouilles Exécutées à Mallia, Le Quartier Mu, II, Études Crétoises, 26: 235-238. Paris.

Poursat, J.-C., 1992, Guide de Malia au temps ties premiers palais, Le Quartier Mu, École Française d'Athènes. Sites et Monuments, VIII.

Raban, A., 1988, The constructive maritime role of the Sea Peoples in the Levant. Society and Economy in the Eastern Mediterranean (c.1500-1100 B.C.), Proceedings of the International Symposium, Haifa, May 1985 (Heltzer, M. \& Lipinski, E., Eds). Leuven.

Schaeffer, C. F. A., 1978, Remarques sur les ancres en pierre d'Ugarit. Ugaritica, VII: 371-381). Mission de Ras Shamra. Paris.

Shaw, J. W., 1973, Minoan architecture: materials and techniques. Annuario delta Scuola Archeologica di Atene XLIX, (N.S. XXXIII 1971). Rome.

Shaw, J. W., 1984, Excavations at Kommos (Crete) during 1982-1983. Hesperia, 53: 251-287.

Shaw, J. W. \& Blitzer, H., 1983, Stone weight anchors from Kommos, Crete. IJNA, 12: 91-100. Shaw, J. W. \& Shaw, M. C., 1993, Excavations at Kommos (Crete) during 1986-1992. Hesperia, 62; 129190.

Shaw, J. W. \& Shaw M. C. (Eds), 1995, Kommos, I: The Kommos Region and Houses of the Minoan Town. Part 1, The Kommos Region, Ecology, and Minoan Industries. Princeton.

Shaw, J. W. \& Shaw, M. C., in press, A proposal for Bronze Age Aegean ship-sheds in Crete. Tropis.

Shaw, M. C., 1985, Late Minoan I buildings J/T, and Late Minoan III buildings N and P at Kommos: their nature and possible uses as residences, palaces, or emporia. In: Shaw, J. W. \& Shaw, M. C. (Eds), A Great Minoan Triangle in Southcentral Crete: Kommos, Hagia Triadha, Phaistos. Scripta Mediterranea, 6: 19-25. Toronto.

Steininger, F. F., Series, J., Kleemann, K. \& Rögl, F., 1985, Neogene of the Mediterranean Tethys and Paratethys, Stratigrophic Correlation Tables and Sediment Distribution Maps, I and II. Vienna.

Tsipopoulou, M., 1989. A Minoan anchor from Petras, Siteias. AE 128: 121-128.

Wachsmann, S., in press, Seagoing Ships and Seamanship in the Bronze Age Levant.

Warren, P. \& Hankey, V., 1989, Aegean Bronze Age Chronology. Bristol.

Watrous, L. V., 1992, The Late Bronze Age Pottery. Kommos, III (Shaw, J. W. \& Shaw, M. C.[Eds]). Princeton. 